\title{
Metody badań edukacji przedsiębiorczej
}

\author{
The Research Methods of Entrepreneurship Education
}

Podziękowania dla dr. hab. Adama Sadowskiego, prof. UwB, za cenne uwagi.

Podziękowania dla dr Elżbiety Misiewicz.

Streszczenie: Inwestycje w edukację, jak wynika z wielu badań, przynoszą korzyści materialne zarówno jednostkom, jak i społeczeństwu, jednakże ciągle otwartą kwestią pozostaje, które rodzaje edukacji najsilniej wpływają na postawy przedsiębiorcze, będąc istotnymi determinantami wzrostu gospodarczego. Ważne z tego punktu widzenia jest prowadzenie badań w tym zakresie. Zauważyć jednocześnie należy, że istnieje wiele metod badawczych stosowanych w badaniach edukacji i przedsiębiorczości. Jednym $z$ istotnych problemów dotychczasowych badań przedsiębiorczości oraz relacji przedsiębiorczość - edukacja jest niemożność porównywania ich wyników. Badacze z różnych krajów stosują różne miary przedsiębiorczości i edukacji. Ich lepsza znajomość może istotnie przyczynić się do opracowania skutecznych programów nauczania przedsiębiorczości. Niniejszy artykuł ma zatem na celu charakterystykę metod badania związków edukacji i przedsiębiorczości. Przegląd dotyczy artykułów napisanych na podstawie badań z różnych, dostępnych autorce źródeł, wydanych w okresie 2012-2015, uzupełnionych o przegląd literatury w tym zakresie ${ }^{1}$.

\begin{abstract}
Investments in education bring tangible benefits to both the individuals as well as the society, however, it is still an open question what kind of education has the strongest influence on entrepreneurial attitudes, being important determinants of economic growth. Important from this point of view is to conduct research in this area. There should also be noted that there are many research methods used in studies of education and entrepreneurship. One of the major problems of previous studies of entrepreneurship and entrepreneurship - education relationship is the inability to compare their results. Researchers from different countries use different measures of entrepreneurship and education. Better knowledge of them can significantly contribute to the development of effective programs of entrepreneurship education. The paper's aim is to characterize the research methods of studying the connection between education and entrepreneurship. The review of articles written on the basis of research, from different available sources for the author during the period: 2012-2015, was complemented by a review of the literature in this area.
\end{abstract}

${ }^{1} \mathrm{~W}$ artykule przytoczono jedynie kilka wybranych opracowań poruszających problematykę przedsiębiorczości i zagadnienia jej kształtowania, niemniej opracowań w tym zakresie jest bardzo dużo, można tu wskazać m.in.: Draghbashyan, Harsman (2014); Izzrech, Giudice, Peruta (2013). 
Słowa kluczowe: edukacja; edukacja przedsiębiorcza; metody badawcze; przedsiębiorczość

Key words: education; entrepreneurship; entrepreneurship education; research methods

Otrzymano: 9 stycznia 2016

Received: 9 January 2016

Zaakceptowano: 6 marca 2016

Accepted: 6 March 2016

\section{Sugerowana cytacja/Suggested citation:}

Andrzejczyk, A. (2016). Metody badań edukacji przedsiębiorczej. Przedsiębiorczość - Edukacja, 12, $352-363$.

\section{Wstęp}

Inwestycje w edukację są konieczne w tworzeniu potencjału wzrostu gospodarczego (Zimnoch, 2012). Wzrost wykształcenia wpływa dodatnio na zarobki społeczeństwa, a tym samym wysokość odprowadzanych podatków, satysfakcję z życia, stan zdrowia, zaangażowanie społeczne (Zimnoch, 2012), a także efektywność prowadzenia firmy (Węcławska, Tarnawa, Zadura-Lichota, 2012). Od lat rośnie wysokość nakładów na edukację w przeliczeniu na ucznia/ studenta, jednakże w XXI w. nie wpłynęło to zdecydowanie na poprawę jakości kształcenia. Dostrzeżono konieczność zmiany z modelu nauki opartego na ścisłym przekazywaniu wiedzy na model oparty na kształtowaniu umiejętności i postaw (Zimnoch, 2012). System edukacji ma za zadanie przekazywać zatem wiedzę, kształtować umiejętności i postawy jego uczestników, również w zakresie przedsiębiorczości.

Mnogość podejść w zakresie edukacji przedsiębiorczej nie ułatwia badań również ze względu na wielość definicji przedsiębiorczości. Przekłada się to na różnorodność stosowanych metod i kombinacji poszczególnych elementów edukacji i przedsiębiorczości w procesie badawczym.

Dokonywane próby badania zależności między edukacją przedsiębiorczą a rozwojem przedsiębiorczości reprezentują różne podejścia badawcze. W związku z licznymi różnicami postanowiono nieco uporządkować wiedzę z tego zakresu i tym samym zaprezentować stosowane metody badawcze. Poszczególne ich istotne elementy uporządkowano w tabeli 1. Nie znaczy to, że to jedyne elementy metodyczne, gdyż takie informacje, jak przyjęte skale odpowiedzi, metoda doboru próby czy wymiar czasowy, zdarzają się nie być ujmowane w opracowaniach. Do analizy starano się wybrać najnowsze artykuły badawcze z zakresu przedsiębiorczości i edukacji. Lepsza znajomość metod badania edukacji przedsiębiorczej może w istotny sposób wspomóc opracowanie skutecznych programów nauczania przedsiębiorczości. Za cel pracy przyjęto charakterystykę metod badania związków edukacji z przedsiębiorczością na podstawie wybranych artykułów z różnych, dostępnych autorce źródeł wydanych w latach 2012-2015, uzupełnioną o przegląd literatury w tym zakresie. Istotnym elementem opracowania są również wyniki badań własnych autorki.

\section{Definicje przedsiębiorczości i sposoby jej pomiaru}

W terminologii ekonomicznej używanie terminu „przedsiębiorczość” zostało zapoczątkowane i upowszechnione dzięki badaniom R. Cantillona dopiero w połowie XVIII w. 
Mimo upływu czasu oraz kolejnych prób definiowania i określania znaczenia przedsiębiorczości w świetle teorii ekonomii nie ma jednoznacznego stanowiska wobec definicji przedsiębiorczości.

Bogata historia przedsiębiorczości swoje źródła ma w znaczeniu tego zjawiska dla gospodarki i społeczeństwa. W rozumieniu zakładania, prowadzenia i rozwijania własnej działalności gospodarczej przedsiębiorczość to prosta metoda na efektywne wykorzystanie lokalnych zasobów (Bończak-Kucharczyk, Herbst, Chmura, 1998). Przedsiębiorcy przyczyniają się nie tylko do ich wykorzystania, ale też do tworzenia innowacji. Jednostki przedsiębiorcze kształtują zatem gospodarkę kraju i kierunki jej rozwoju (Glinka, Gudkova, 2011). Jednakże definicja ta nie oddaje całego spektrum znaczeń przypisywanych omawianemu pojęciu. Dlatego też, w zależności od tego, kto podejmuje się zdefiniowania pojęcia, jest ono kształtowane na wzór zainteresowania i wiedzy badacza (Roszkowska-Mądra, Parfieniuk, Studnicki, 2014).

Warto zwrócić uwagę na to, że również w aspekcie historycznym, pierwsze ujęcie terminu „przedsiębiorczość” dotyczyło indywidualnych zachowań i postaw pojedynczych osób. Autorzy zwykle koncentrowali swoje zainteresowania właśnie na przedsiębiorczości indywidualnej (Piecuch, 2010). Ze względu na podjęty temat w niniejszej pracy skupiono uwagę na wymiarze jednostkowym przedsiębiorczości - osobie przedsiębiorczej.

W podejściu skupiającym się na osobie przedsiębiorczej brane pod uwagę są jej cechy i predyspozycje. Cechy osobowości mogą zostać wzmocnione w procesie edukacji, a w odpowiednich, sprzyjających warunkach również wykształcone u tych osób, które ich nie posiadają (Brajer-Marczak, Marciszewska, 2008).

M. Bratnicki i J. Strużyna podkreślają, że przedsiębiorczość to sposób bycia. Przedsiębiorczość to proces, który jest na tyle złożony, że można ująć go jako specyficzny sposób postrzegania świata, myślenia i działania, który pozwala na kreowanie i wykorzystywanie szans rozwojowych. Pracę przedsiębiorcy określają natomiast jako formę poszukiwania, identyfikowania, wykorzystywania i rozwijania dostrzeżonych szans (Jamka, 2012), ponieważ przedsiębiorczość można postrzegać jako poszukiwanie i eksplorację dostrzeżonych szans (Shane, Venkataraman, 2000).

Przedsiębiorczość to zatem typ aktywności ludzi polegający na wykorzystaniu pojawiających się w otoczeniu okazji, przez realizację własnych przedsięwzięć przynoszących efekty ekonomiczne i/lub pozaekonomiczne ich podmiotom lub otoczeniu (Dembińska, 2012). Współczesna przedsiębiorczość powinna się odnosić do wszelkiej aktywności ludzi - nie tylko do działalności gospodarczej. Przedsiębiorczość jest więc pożądanym sposobem zachowania się i radzenia sobie w trudnych warunkach otoczenia (Piecuch, 2010), a nowoczesny człowiek to m.in. człowiek przedsiębiorczy (Dembińska, 2012). Zachowanie oparte na wykrywaniu szans, chęci podążania za nimi, pewności siebie i możliwości odniesienia sukcesu stają się kluczowym elementem procesu przedsiębrania (Stevenson, Jarillo, 1990).

Rozważania o przedsiębiorczości mogą dotyczyć zatem jednostek, które przyjęły przedsiębiorczą postawę, ale mogą również odnosić się do efektu ich działania, np. przedsiębiorstwa, wyróżniającej się aktywności społecznej.

Przedsiębiorczość mierzona jest na wiele sposobów. Tak, jak nie istnieje jednoznaczna definicja przedsiębiorczości, tak pomimo wielokrotnych analiz zjawiska przedsiębiorczości, jednoznaczna metoda pomiaru i oceny przedsiębiorczości wydaje się być niemożliwa. Przyczyną problemu pomiaru i oceny przedsiębiorczości jest to, że przedsiębiorczość należy do zagadnień bardzo złożonych i niełatwych do realizacji w praktyce. Co więcej, nie istnieje jeden uniwersalny sposób, procedura czy też zestaw mierników przedsiębiorczości. W związku 
z powyższym, w celu pomiaru i analizy przedsiębiorczości stosuje się wiele koncepcji i podejść (Duraj, Papiernik-Wojdera, 2010).

Przedsiębiorczość zwykle mierzona i oceniana jest w dwóch wymiarach: przestrzennym, np. lokalnym, krajowym, regionalnym, a także ze zróżnicowaniem ze względu na sektor, branżę, przemysł, jednostki gospodarcze (np. przedsiębiorstwa, instytucje), oraz - coraz częściej - w wymiarze jednostkowym (poza aspektem gospodarczym), gdyż każdy człowiek może wykazywać postawę przedsiębiorczą (Duraj, Papiernik-Wojdera, 2010).

W efekcie stosowanych podziałów badane zależności mogą być ujmowane za pomocą różnorodnych mierników, przy czym ocena przedsiębiorczości wymaga zastosowania zarówno kryteriów ilościowych, jak i jakościowych. Należy pamiętać, że przedsiębiorczość nie może być ograniczana jedynie do liczby nowo powstałych przedsiębiorstw, wprowadzonych na rynek wyrobów czy podjętych inicjatyw prorozwojowych (Duraj, Papiernik-Wojdera, 2010). Mimo to większość prowadzonych badań oparta jest na metodach ilościowych. Posługując się w badaniach nad przedsiębiorczością głównie tymi metodami, mimo ich obiektywności, rzetelności i trafności, można odnieść wrażenie istotnej straty części zjawiska przedsiębiorczości związanej z subiektywną wiedzą osób przedsiębiorczych o ich działaniu (Dembińska, 2012) oraz przejawianą postawą w życiu możliwą do zbadania w badaniach jakościowych.

W związku z dużym zainteresowaniem przedsiębiorczością w ostatnich latach i jej wpisaniem do wielu realizowanych obecnie programów w niniejszym opracowaniu zwrócono szczególną uwagę na kształtowanie postaw przedsiębiorczych uczestników procesu edukacji.

\section{Stosowane metody badań edukacji przedsiębiorczej}

Edukacja to całokształt procesów wychowawczych i kształcących człowieka (Mróz, Siwińska, 2013). „Celem edukacji jest wychowanie w świadomości bycia autonomiczną osobą, obdarzoną godnością oraz świadomego i odpowiedzialnego uczestnictwa w życiu społecznym" (Brzozowski, 2012: 116) oraz wyposażenie uczestnika systemu edukacji w instrumenty intelektualne, które pozwolą mu na samodzielne zgłębianie wiedzy oraz obiektywną ocenę odbieranych danych (Brzozowski, 2012). Oznacza to, że w drodze edukacji człowiek nabywa wiedzę i umiejętności, ale też kształtuje się jego osobowość i postawa wobec otaczającego świata.

Edukacja stanowi kluczową determinantę kształtowania ludzkich postaw, umiejętności i kultury, dlatego też należy edukację przedsiębiorczą kierować do jak najmłodszych odbiorców (Entrepreneurship Education..., 2012), a następnie kontynuować ją i wśród studentów (Kida, 2012), i wśród doktorantów (Wach, 2012). Nie można też zapomnieć o edukacji przedsiębiorczej na późniejszych etapach życia. Edukacja w tym obszarze jest istotna nie tylko ze względu na kształtowanie sposobu myślenia ludzi, lecz także ze względu na zdobywane przez nich umiejętności i wiedzę, które ostatecznie przekładają się na rozwój kultury przedsiębiorczej na danym obszarze oddziaływania (Entrepreneurship Education..., 2012). Jednym z celów edukacji przedsiębiorczej jest również zachęcanie, szczególnie studentów, do rozpoczęcia kariery przedsiębiorcy (Chen et al., 2015).

W literaturze występują różne podejścia do zagadnienia edukacji przedsiębiorczej. Można mówić o: 1. edukacji o przedsiębiorczości, opartej na przekazywaniu wiedzy teoretycznej z zakresu zakładania i prowadzenia własnej działalności gospodarczej; 2. edukacji dla przedsiębiorczości, kształtującej umiejętności potrzebne przedsiębiorcom w prowadzeniu własnego przedsiębiorstwa; 3. edukacji przez przedsiębiorczość, o dominującej roli edukowania 
aktywnych przedsiębiorców w kontekście dalszego rozwoju umiejętności biznesowych (Wach, 2013). W tych trzech ujęciach dominuje pojęcie przedsiębiorczości w kontekście prowadzenia własnej działalności gospodarczej, a nacisk kładziony jest na zdobywanie niezbędnej wiedzy teoretycznej, kształtowanie umiejętności przydatnych przedsiębiorcy w firmie, aż po ich dalszy rozwój.

Wyróżniana jest też edukacja w zakresie przedsiębiorczego dynamizmu, która ma za zadanie promowanie postaw (cech) przedsiębiorczych nie tylko w sferze własnej działalności gospodarczej, lecz także w życiu codziennym (Wach, 2013). To ostatnie podejście szczególnie inspiruje autorkę do badań związków między edukacją a przedsiębiorczością. Zbliżony podział na cztery kategorie edukacji przedsiębiorczej prezentuje T.L. Jensen (są to kategorie: about, for, through, embedded). Autor ten przeprowadził analizy treści wybranych badań z zakresu wpływu edukacji przedsiębiorczej, spójności zrozumienia definicji przedsiębiorczości, celów edukacji przedsiębiorczej oraz zaprezentował ocenę dotychczas stosowanych metod, a także przedstawił własne studium przypadku (Jensen, 2014).

Tab. 1. Istotne elementy stosowanych podejść w badaniu związków edukacji przedsiębiorczej z przedsiębiorczością

\begin{tabular}{|c|c|c|c|c|}
\hline $\begin{array}{c}\text { Definicja } \\
\text { przedsiębiorczości }\end{array}$ & $\begin{array}{c}\text { Postawa } \\
\text { przedsiębiorcza }\end{array}$ & $\begin{array}{c}\text { Założenie } \\
\text { i prowadzenie } \\
\text { przedsiębiorstwa }\end{array}$ & $\begin{array}{c}\text { Postawa, } \\
\text { założenie } \\
\text { i prowadzenie } \\
\text { przedsiębiorstwa }\end{array}$ & $\begin{array}{l}\text { Inne działania, } \\
\text { w tym społeczne }\end{array}$ \\
\hline $\begin{array}{l}\text { Definicja edukacji } \\
\text { przedsiębiorczej }\end{array}$ & $\begin{array}{l}\text { edukacja } \\
\text { o przedsiębiorczości }\end{array}$ & $\begin{array}{l}\text { edukacja dla } \\
\text { przedsiębiorczości }\end{array}$ & $\begin{array}{l}\text { edukacja przez } \\
\text { przedsiębiorczość }\end{array}$ & \begin{tabular}{|l|} 
edukacja \\
w zakresie \\
przedsiębiorczego \\
dynamizmu \\
\end{tabular} \\
\hline Cele badań & eksploracyjne & opisowe & wyjaśniające & \\
\hline Jednostka analizy & $\begin{array}{l}\text { studenci (zwłaszcza } \\
\text { kierunków i/lub } \\
\text { kursów związanych } \\
\text { z przedsiębiorczością) }\end{array}$ & nauczyciele & $\begin{array}{l}\text { programy } \\
\text { nauczania }\end{array}$ & inne grupy \\
\hline Typy obserwacji & $\begin{array}{l}\text { badania sondażowe } \\
\text { (ankieta do } \\
\text { samodzielnego } \\
\text { wypełnienia, } \\
\text { telefoniczna, wywiad } \\
\text { ankietowy) }\end{array}$ & $\begin{array}{l}\text { badania } \\
\text { niereaktywne } \\
\text { (analizy treści, } \\
\text { istniejących danych } \\
\text { statystycznych, } \\
\text { historyczna } \\
\text { i porównawcza) }\end{array}$ & $\begin{array}{l}\text { badania } \\
\text { ewaluacyjne }\end{array}$ & eksperyment \\
\hline Liczebność próby & $\begin{array}{l}\text { case study (mała } \\
\text { grupa) }\end{array}$ & $\begin{array}{l}\text { mikrodane (badania } \\
\text { niereprezentatywne) }\end{array}$ & makrodane & \\
\hline
\end{tabular}

Źródło: opracowanie własne

W pomiarze rezultatów edukacji przedsiębiorczej w T.L. Jensen wyróżnił trzy kategorie: ocenę nauczycieli i studentów z różnych perspektyw (w tym ocenę postawy), liczbę przedsiębiorstw założonych przez studentów oraz kombinację dwóch wcześniejszych, które właściwie odnoszą się do przyjętej w badaniu definicji przedsiębiorczości. Zwrócił on również uwagę na respondentów poddawanych badaniu, gdyż w literaturze głównie bada się osoby, które albo 
studiowały kierunek ściśle związany z przedsiębiorczością, albo uczestniczyły w specjalnych kursach przygotowujących $\mathrm{z}$ danego zakresu. Co więcej, określił, że pewnym odstępstwem jest ocena samych kursów (bądź programów nauczania), która prowadzona jest $\mathrm{z}$ reguły przed uczestnictwem w zajęciach, w trakcie oraz po (do sześciu miesięcy) (Jensen, 2014).

Jensen zwrócił także uwagę na związek badań z dyscypliną, wskazując na to, że większość analizowanych przez niego badań dotyczy studentów będących na uczelni i uczących się na kierunkach ściśle związanych z przedsiębiorczością, np. takich jak zarządzanie na uczelniach biznesowych. Wyjątek stanowią dwa wspomniane przez niego badania: przeprowadzone w 2006 r. w Wielkiej Brytanii, w którym to studenci pochodzili z różnych kierunków studiów, w tym inżynierskich; oraz jego własne badania przeprowadzone na kierunkach humanistycznych w 2012 r. na Uniwersytecie Południowej Danii (Jensen, 2014)2.

Studium przypadku z Danii miało na celu opisanie, jak studenci rozwijają swoją przedsiębiorczość w trakcie kursów, w przerwach między kursami oraz w życiu codziennym. Zajęcia głównie opierały się na przekazywaniu wiedzy z zakresu przedsiębiorczości oraz kształceniu dla przedsiębiorczości/przez przedsiębiorczość, a ostatecznie ukończyło je 12 osób. Po zakończeniu kursu oceniano również liczbę podjętych lub planowanych działań społecznych kursantów. Badanie to opierało się na wprowadzeniu do analizy perspektywy holistycznego ujęcia osoby w badaniach edukacji przedsiębiorczej (Jensen, 2014).

Wśród badań, do których dotarła autorka, jedno obejmowało case study instytucji - uniwersytetu badawczego Eastern State University. W badaniu posłużono się analizą literatury przedmiotu, wywiadami oraz analizą dokumentów. W 2013 r. badaniu poddano 31 różnych jednostek: administratorów uniwersytetu, kadry, członków wydziału, studentów. Zastosowano dobór celowy, na podstawie posiadanej wiedzy, tj. wybierano te osoby, które zarządzały akademickimi przedsięwzięciami, nadzorowały centra przedsiębiorczości, prowadziły kursy z tego zakresu lub w nich uczestniczyły. Nagrane i spisane wywiady uzupełniono o istotne treści z dokumentów: sylabusów z kursów przedsiębiorczości, informacji prasowych, katalogów kursów, instrukcji itd. Celem badania było odkrycie, dlaczego badany uniwersytet zainicjował oraz wsparł programowe i komplementarne do nich propozycje zmian angażujące wszystkich studentów pierwszego stopnia w obszarze innowacji i przedsiębiorczości w latach 2010-2013. Jednym z interesujących wniosków było to, że wielu respondentów dostrzegło potrzebę kształtowania umiejętności przedsiębiorczych u studentów ze względu na dynamiczne i zmienne otoczenie (McClure, 2015).

Również badacze $\mathrm{z}$ Tajwanu podjęli się analizy literatury przedmiotu i, jako nieliczni z badających, prowadzili badania przedsiębiorczości w kontekście edukacji w formie eksperymentu. W opracowaniu przedsiębiorczość utożsamili z przedsiębiorcą pracującym na własny rachunek. Badanie to miało na celu sprawdzenie, czy uczestnictwo w kursie z przedsiębiorczości zwiększy intencje przedsiębiorcze kursantów, ich satysfakcję wobec kursu z przedsiębiorczości i efektywność uczenia się studentów uniwersytetu technicznego (Chen et al., 2015).

W eksperymencie wzięło udział 41 studentów ostatniego roku Wydziału Marketingu i Logistyki Państwowego Uniwersytetu Nauki i Technologii Penghu na Taiwanie, którzy uczestniczyli w 18-tygodniowym, nadobowiązkowym kursie z zakresu zarządzania innowacyjnością

\footnotetext{
${ }^{2}$ Jest to o tyle interesujące, że autorka niniejszego opracowania w 2015 r. przeprowadziła badanie dotyczące związków edukacji z przedsiębiorczością na wszystkich uczelniach (16 uczelni) i kierunkach studiów (81 kierunków, w tym: medyczne, techniczne, społeczne) w semestrze letnim w województwie podlaskim. Wskazywałoby to, że badania te są jednym z nielicznych przykładów tak szerokiej próby badawczej. Badanie własne autorki zostanie omówione w dalszej części artykułu.
} 
i przedsiębiorczością, przeprowadzonym w ciągu jednego semestru. Edukacja podczas kursu obejmowała nauczanie o przedsiębiorczości i dla przedsiębiorczości. Kurs prowadził instruktor, a dodatkowo przez sześć tygodni zajęcia współprowadził mentor biznesu, który miał przedsiębiorcze doświadczenie, również z porażką w prowadzeniu przedsiębiorstwa (Chen et al., 2015).

Opinie studentów zebrano, używając kwestionariusza ankiety zawierającego pytania będące kompilacją zebranych przez badacza materiałów z literatury przedmiotu. Badanie przeprowadzono przed i po zakończeniu kursu. Wyniki z tego badania są o tyle interesujące, że studenci byli usatysfakcjonowani kursem, ich wiedza i umiejętności wzrosły, ale intencje do założenia własnego przedsiębiorstwa nieznacznie spadły. Badacze argumentowali taki stan tym, że studenci przekonali się, jak trudnym przedsięwzięciem jest prowadzenie własnej działalności i że taka kariera może nie być dla nich (Chen et al., 2015).

Jedno $\mathrm{z}$ analizowanych opracowań obejmowało badanie postaw przedsiębiorczych na podstawie pięcioczynnikowego modelu osobowości warunkowanego cechami przedstawionymi przez Costy i McCrae, a celem badań było powiązanie cech osobowości ze wskaźnikami działania firmy. Badaniu poddano w tym wypadku 124 uczestników jednego z programów stymulacji przedsiębiorczości z Programu Operacyjnego Kapitał Ludzki, z których 81 założyło własną działalność. Osoby te w ramach projektu korzystały ze szkoleń i doradztwa biznesowego oraz uczestniczyły w konkursie o dotację na założenie firmy. Edukacja w tym wypadku dotyczyła edukacji: o, dla przedsiębiorczości, przez przedsiębiorczość i przez przedsiębiorczy dynamizm. Obejmowała osoby w różnym wieku (23-61 lat), o różnym wykształceniu (średnie lub wyższe), co mogło mieć wpływ na różnice w wynikach. Efektywność funkcjonowania przedsiębiorstwa zmierzono ośmioma zagregowanymi wskaźnikami za pomocą ankiety. Pomiędzy pomiarem postawy kandydatów a oceną funkcjonowania firmy minęło osiem miesięcy. Co więcej, w artykule dokonano analizy literatury przedmiotu również w ujęciu modelowym, przedstawiono propozycję własnego modelu badania uwarunkowań procesu zostawania przedsiębiorcą (Kaczmarek, 2014).

Kolejne analizowane opracowanie obejmowało badania $\mathrm{z}$ zakresu przedsiębiorczości przeprowadzone na grupie 45 studentów zaocznych drugiego i trzeciego roku zarządzania Katolickiego Uniwersytetu Lubelskiego. Badanie to miało m.in. na celu analizę psychologiczną przedsiębiorczości, kreowania postaw przedsiębiorczych oraz charakterystykę nauczania przedsiębiorczości. Na podstawie analizy literatury przedmiotu oraz wyników badań dokonano rozważań dotyczących właściwych modeli nauczania przedsiębiorczości. Co ciekawe, w wyjaśnieniu uwarunkowań nauczania przedsiębiorczości zwrócono uwagę na to, że przedsiębiorczość akademicka powinna być rozumiana jako nie tylko biznesowe wykorzystanie wyników badawczych, ale też w kontekście indywidualnych przedsięwzięć młodzieży akademickiej. Zastosowano również kwestionariusz ankiety, w którym m.in. pytano o stopień przygotowania do prowadzania własnej działalności gospodarczej, źródła informacji dotyczących prowadzenia przedsiębiorstwa i sposoby powiązania uczelni z gospodarką. Ankietę uzupełniono treściami uwag studentów (Kida, 2012).

Postawy i zachowania przedsiębiorcze 600 studentów dziennych 6 wrocławskich uczelni, ich uwarunkowania oraz postrzeganie przez nich systemu edukacji w odniesieniu do kształtowania postaw przedsiębiorczych zbadano w 2011 r. Dobrani losowo studenci reprezentowali kierunki ekonomiczne, techniczne, humanistyczne, sportowe i byli studentami studiów pierwszego stopnia i jednolitych studiów magisterskich (głównie ostatnich lat). W krótkim wprowadzeniu zwrócono uwagę na wąską i szeroką definicję przedsiębiorczości. W badaniu 
posłużono się kwestionariuszem ankiety opracowanym w ramach Międzynarodowych Badań Studentów Studiów Dziennych - SES 2006. W zakresie edukacji skupiono się głównie na wiedzy teoretycznej z obszaru bloków tematycznych i zajęć z zakresu prowadzenia własnej działalności gospodarczej. Co więcej, w analizowanym artykule odniesiono się również do wyników badań z roku wcześniejszego (Brajer-Marczak, Marciszewska, 2012).

\section{Badania własne przedsiębiorczości młodzieży akademickiej}

Przy analizie dotychczasowego dorobku naukowego w zakresie badań związków w obszarach edukacja - przedsiębiorczość dostrzeżono wiele różnic w podejściach badawczych stosowanych przez naukowców z różnych krajów. Mając na względzie to, jak istotny wpływ na ostateczne wyniki procesu badawczego ma zastosowana metoda badawcza, postanowiono przeprowadzić badania własne wśród studentów w semestrze letnim roku akademickiego 2014/2015 w województwie podlaskim. Za trzy główne cele badań przyjęto: określenie poziomu postawy przedsiębiorczej studentów, zidentyfikowanie występujących związków (i ich siły) postaw studentów z prowadzeniem przez nich własnej działalności gospodarczej z uczestnictwem w wybranych formach edukacji formalnej i nieformalnej, a także zbadanie, jak studenci oceniają poszczególne formy edukacji.

W badaniu przyjęto szeroką definicję przedsiębiorczości obejmującą postawy przedsiębiorcze oraz zakładanie i prowadzenie własnej działalności gospodarczej, które uzupełniono o dodatkowe aktywności podejmowane przez badaną młodzież akademicką. Edukacja przedsiębiorcza została zaś określona jako o, dla przedsiębiorczości i przez przedsiębiorczy dynamizm. Badanie obejmowało studentów reprezentujących wszystkie funkcjonujące w tym czasie uczelnie wyższe i kierunki studiów, łącznie 19 uczelni (oddziały zamiejscowe uczelni znajdujące się w innych jednostkach administracyjnych w obszarze województwa podlaskiego zostały ujęte jako oddzielne jednostki uczelniane) oraz 81 kierunków studiów, które pogrupowano w 21 grup kierunków wzorowanych na metodologii Głównego Urzędu Statystycznego. Minimalną próbę określono na poziomie 1843 studentów. Jednak w związku z tym, że niektóre mniejsze uczelnie i kierunki studiów o mniejszej liczbie studiujących na nich osób przy przyjętych założeniach weszłyby do próby w wartościach ułamkowych, poszerzono próbę i ostatecznie, w drodze zaokrągleń, liczebność próby przyjęta do badań wyniosła 2004 osoby. Zastosowano dobór proporcjonalny, a losowanie grup zajęciowych odbyło się na podstawie uzyskanych rozkładów zajęć. Stosując powyższe metody, starano się jak najdokładniej odzwierciedlić populację generalną. W doborze próby zastosowano losowy dobór warstwowy, a w badaniu wykorzystano kwestionariusz ankiety do samodzielnego wypełnienia, skonstruowany specjalnie do potrzeb tego badania.

Pozyskane dane mogą przyczynić się do wypromowania najefektywniejszych form edukacji. Badanie uzupełniono o 104 poszerzone wywiady ankietowe z przedsiębiorcami zarejestrowanymi w województwie podlaskim, przeprowadzone w okresie letnim 2015 r. (należy zaznaczyć, że próba ta jest znacznie mniejsza od minimalnej, wynoszącej prawie 400 przedsiębiorców) oraz wypowiedzi w zakresie przedsiębiorczości specjalistów z różnych grup (nauczyciele szkół średnich i przedstawiciele kuratorium oświaty, nauczyciele akademiccy, naukowcy, przedstawiciele instytucji otoczenia biznesu, przedstawiciele władz i instytucji lokalnych, przedsiębiorcy). 
Jako jeden z licznych, interesujących wniosków z przeprowadzonych badań można przytoczyć ocenę form edukacyjnych $\mathrm{w}$ procesie kształcenia postaw przedsiębiorczych dokonaną przez studentów. Szczególnie wysoko (w skali od 1 do 5) oceniono ${ }^{3}$ szkolenia praktyczne $(4,16)$, płatne staże zawodowe $(4,13)$ i praktyki zawodowe $(4,07)$, tj. formy o silnym akcencie praktycznym.

W badaniu określono również postawę przedsiębiorczą studentów na podstawie 13 stwierdzeń, do których ustosunkowywali się respondenci („Łatwo nawiązuję kontakt z innymi ludźmi”; „Nie boję się nietypowych rozwiązań”; „Umiem brać odpowiedzialność za podejmowane działania”; „Posiadam umiejętności organizacyjne”; „Pojawiające się problemy traktuję jako wyzwania”; „Chętnie angażuję się w nowe przedsięwzięcia”; „Lubię przejmować inicjatywę w realizowanych przedsięwzięciach”; „Łatwo dostosowuję się do zmian zachodzących w moim otoczeniu”; „Posiadam wiele pomysłów, które chciałabym/chciałbym zrealizować”; „Kiedy wyznaczę sobie jakiś cel, ciężko pracuję, by go osiągnąć”; „Podejmuję działania w zakresie rozwoju osobistego”; „W trudnych sytuacjach jestem opanowana/opanowany”; „Uważam, że jestem przedsiębiorcza/przedsiębiorczy"). Odpowiedziom tym przypisano punkty, odpowiednio: zdecydowanie nie - 0 , raczej nie - 1, raczej tak - 2 i zdecydowanie tak - 3. Na tej podstawie zbudowano wskaźnik przedsiębiorczości (nazywany zamiennie wskaźnikiem postaw przedsiębiorczych), który opiera się na średniej punktacji wyznaczonej ze wszystkich stwierdzeń. Wartość wskaźnika przedsiębiorczości oscyluje zatem w przedziale $<0,3\rangle$.

Okazuje się, że postawa przedsiębiorcza studentów różni się w zależności od wielu czynników edukacji. Średnia postawa przedsiębiorcza dla ogółu respondentów wyniosła 2,094, zaś najwyższa wartość ogólnego wskaźnika przedsiębiorczości dotyczyła studentów studiów mających doświadczenie w prowadzeniu własnego przedsiębiorstwa (wartość wskaźnika przedsiębiorczości wynosi 2,304), chcących założyć własną działalność $(2,249)$ i studentów studiów niestacjonarnych $(2,199)$, a najniższa dotyczy studentów studiów stacjonarnych (2040).

Nadmienić należy, że jedynie 5,24\% studentów podlaskich uczelni w dniu badania prowadziło lub prowadziło wcześniej własną działalność gospodarczą. Najwyższy udział studentów prowadzących w dniu badania i/lub w przeszłości działalność gospodarczą był w grupie studentów uczelni niepublicznych (14,49\%) i studentów studiów niestacjonarnych (11\%). Wynik ten ma swoje potwierdzenie $\mathrm{w}$ jednym $\mathrm{z}$ najwyższych wskaźników ogólnych postawy przedsiębiorczej studentów uczelni prywatnych i studiów zaocznych spośród wszystkich badanych grup. Taki wynik może być spowodowany tym, że osoby prowadzące własną działalność gospodarczą lub chcące taką działalność założyć, chcąc uzupełnić bądź zdobyć wykształcenie, mogą częściej wybierać uczelnie prywatne i studia zaoczne. Co więcej, ankietowani studenci prowadzący własną działalność gospodarczą wykazują postawę na poziomie 2,304 przyjętego wskaźnika. Co może oznaczać, że to studenci o najwyższym poziomie wskaźnika przedsiębiorczości są skłonni do podjęcia kariery przedsiębiorcy w rozumieniu założenia i prowadzenia własnej działalności gospodarczej.

Badając przedsiębiorczość młodzieży akademickiej, zapytano również o chęć założenia własnej działalności gospodarczej przez respondentów. Wśród ogółu ankietowanych studentów 18,7\% chce założyć własną działalność gospodarczą, 19,3\% nie chce założyć takiej działalności, a 60,3\% respondentów odpowiedziało, że jeszcze o tym nie myślało. Aż u ponad 60\% studentów mógł nie pojawić się wystarczający bodziec do tego, aby zastanowili się oni nad założeniem i prowadzeniem własnej działalności gospodarczej. Jest to o tyle pozytywny wniosek,

\footnotetext{
${ }^{3}$ Są to oceny uśrednione.
} 
że można przyjąć, że studenci ci nie zostali jeszcze ani zachęceni, ani zniechęceni do założenia własnej działalności gospodarczej.

Pozyskane opinie studentów stanowią jedynie fragment prowadzonych przez autorkę badań, ale mogą stać się przyczynkiem do wzrostu zainteresowania badaczy problemem edukacji w zakresie przedsiębiorczości i kształtowania postaw przedsiębiorczych na różnych typach uczelni i kierunkach kształcenia.

\section{Zakończenie}

Analizując istotne elementy stosowanych podejść w badaniu związków edukacji przedsiębiorczej i przedsiębiorczości, uporządkowane w tabeli 1, dostrzeżono, że definicja przedsiębiorczości coraz częściej wykracza poza wąskie ujęcie zakładania i prowadzenia własnej działalności, a włącza się w nią również cechy i zachowania formujące postawę przedsiębiorczą. Gdy jeszcze kilka lat temu autorka zainteresowała się badaniami związków edukacji z przedsiębiorczością, artykuły ujmujące przedsiębiorczość w kontekście postaw, własnej działalności gospodarczej oraz różnych przedsięwzięć, nie tylko gospodarczych, stanowiły rzadkość.

Pomimo funkcjonujących czterech rodzajów edukacji przedsiębiorczej (o, dla przedsiębiorczości, przez przedsiębiorczość i przez przedsiębiorczy dynamizm) w przytoczonych badaniach najczęściej wskazywana jest edukacja o przedsiębiorczości i dla przedsiębiorczości. I najczęściej też badani są studenci, tj. aktywni uczestnicy procesu edukacji wyższej; zwłaszcza studiujący na kierunkach kształcenia związanych z przedsiębiorczością. Rzadziej pojawiają się analizy obejmujące studentów kształcących się na innych kierunkach studiów czy też inne grupy, takie jak: przedsiębiorcy, nauczyciele akademiccy.

Wśród analizowanych badań pojawiają się wszystkie cele: eksploracyjne, opisowe i wyjaśniające, a także różne ich kombinacje; a wśród typów obserwacji dominują badania sondażowe (również powtarzane w różnych odstępach czasu) i badania niereaktywne w postaci analizy treści. Rzadkością są natomiast eksperymenty, które w ekonomii stanowią właściwie stosunkowo nowy obszar (ekonomia eksperymentalna zapoczątkowana została dopiero w latach 40. i 50. XX w.). Dominują case studies i małe liczebności badanych grup, co jest raczej przewidywalnym zjawiskiem w związku z dużą kosztownością prowadzenia badań na szerszą skalę. Takie badania dominują w różnego typu światowych raportach, np. Global Entrepreneur Monitor, Amway: Światowy raport na temat przedsiębiorczości.

Mimo to, dzięki uzyskaniu finansowania własnego pomysłu, autorce udało się przeprowadzić badania wśród studentów w skali województwa podlaskiego, wykraczając znacznie poza próbę minimalną, uzupełniając badania o dane zebrane wśród innych jednostek, korzystając z kilku typów obserwacji. W badaniu przyjęto trzy cele główne: określenie postawy przedsiębiorczej studentów, zidentyfikowanie związku postaw studentów i prowadzenia przez nich własnej działalności gospodarczej z uczestnictwem w wybranych formach edukacji formalnej i nieformalnej oraz rozpoznanie oceny poszczególnych form edukacji w kontekście rozwoju przedsiębiorczej postawy dokonanej przez studentów.

Analizowane elementy stosowanych podejść badawczych w zakresie badań przedsiębiorczości w kontekście edukacji reprezentują jedynie część możliwych rozwiązań. Przedstawione kombinacje nie są również jedynymi możliwymi do zastosowania. Zapoznanie się z dotychczasowymi metodami badawczymi może skutkować wykroczeniem przez naukowców poza przedstawione rozwiązania badawcze, niestosowane dotychczas, co może wpłynąć na rozwój metod badawczych w danym obszarze nauki i ostatecznie doprowadzić do ciekawych wniosków. 
Literatura

References

Bończak-Kucharczyk, E., Herbst, K., Chmura, K. (2015, 27 grudnia), Jak władze lokalne moga wspierać przedsiębiorczość. PARP. Pozyskano z: http://www.parp.gov.pl/files/74/81/93/Lokalne.pdf

Brajer-Marczak, R., Marciszewska, A. (2008). Czynniki warunkujące przedsiębiorczość studentów Dolnego Śląska. Problemy Zarządzania, 1, 170-180.

Brajer-Marczak R., Marciszewska, A. (2012). Postawy przedsiębiorcze studentów wrocławskich uczelni wyższych - wyniki badań. Problemy Zarządzania, 10, 1(36), 144-160.

Brzozowski, T.T. (2012). Przedsiębiorczość jako postawa wobec innych i świata w kontekście procesu budowania płaszczyzny dla dialogu interdyscyplinarnego. Perspektywa pedagogiczno-kulturowa. Przedsiębiorczość - Edukacja, 8, 115-126.

Chen, S., Hsiao, H., Chang, J., Chou, C., Chen, C., Shen, C. (2015). Can the entrepreneurship course improve the entrepreneurial intentions of students?. International Entrepreneurship and Management Journal, 11(3), 557-569.

Dembińska, A. (2012). Metody jakościowe w badaniu przedsiębiorczości. W: Z. Ratajczak (red.), Przedsiębiorczość. Źródła i uwarunkowania psychologiczne, Warszawa: Difin, 214-215.

Duraj, J., Papiernik-Wojdera, M. (2010). Przedsiębiorczość i innowacyjność, Warszawa: Difin.

Entrepreneurship Education at School in Europe. National Strategies, Curricula and Learning Outcomes, 5 (2016, 3 stycznia). Pozyskano z: http://eacea.ec.europa.eu/education/eurydice/documents/thematic_reports/135en.pdf

Glinka, B., Gudkova, S. (2011). Przedsiębiorczość, Warszawa: Wolters Kluwer business.

Jamka, B. (2012). Potencjał ludzki w rozwoju przedsiębiorczości indywidualnej i korporacyjnej, Warszawa: Difin.

Jensen, T.L. (2014). A holistic person perspective in measuring entrepreneurship education impact. Social entrepreneurship education at the Humanities. The International Journal of Management Education, 12, 349-364.

Kaczmarek, M. (2014). Cechy osobowości jako predyktor motywacji i efektywności działań przedsiębiorcy. Problemy Zarzadzania, 12, 1(45), 175-190.

Kida, G. (2012). Kreowanie postaw przedsiębiorczych studentów w ramach zajęć z forum integracji społeczno-gospodarczej na Katolickim Uniwersytecie Lubelskim Jana Pawła II. Problemy Zarzadzania, 10, 1(36), 2, 194-219.

McClure K. R. (2015). Exploring Curricular Transformation to Promote Innovation and Entrepreneurship: An Institutional Case Study, Innovative Higher Education. Innovative Higher Education, 40(5), 429-442.

Mróz, T., Siwińska, M. (2013). Słownik terminów ogólnej teorii kształcenia, Legnica: PWSZ Legnica, 11. Piecuch, T. (2010). Przedsiębiorczość. Podstawy teoretyczne, Warszawa: C.H. Beck.

Roszkowska-Mądra, B., Parfieniuk, A., Studnicki, M. (2014). Poglądy młodzieży akademickiej studiów ekonomicznych o przedsiębiorczości i determinantach jej rozwoju. OPTIMUM. Studia Ekonomiczne, 6(72), 219-220.

Shane, S., Venkataraman, S. (2000). The promise of entrepreneurship as a field of research. Academy of Management Review, 25(1), 217.

Stevenson, H.H., Jarillo, J.C., (1990). A paradigm of entrepreneurship: Entrepreneurial management. Strategic Management Journal, 11, 17-27.

Wach, K. (2012). Kształtowanie postaw przedsiębiorczych w programach nauczania. Stan obecny i proponowane kierunki zmian. W: P. Wachowiak, M. Dąbrowski, B. Majewski (red.), Kształtowanie postaw przedsiębiorczych a edukacja ekonomiczna. Warszawa: Fundacja Promocji i Akredytacji Kierunków Ekonomicznych, 120-127.

Wach, K. (2013). Edukacja na rzecz przedsiębiorczości wobec współczesnych wyzwań cywilizacyjno-gospodarczych. Przedsiębiorczość - Edukacja, 9, 246-257. 
Węcławska D., Zadura-Lichota P. (2010; 2016, 31 lipca). Wpływ edukacji na postawy przedsiębiorcze i przygotowanie młodych Polaków do prowadzenia działalności gospodarczej. W: A. Wilmańska, Raport o stanie sektora malych i średnich przedsiębiorstw w Polsce w latach 2008-2009. Warszawa: Polska Agencja Rozwoju Przedsiębiorczości, Wydawnictwo Naukowe Instytutu Technologii Eksploatacji - PIB, 173-188. Pozyskano z: https://www.parp.gov.pl/files/74/81/380/9282.pdf

Zimnoch, K. (2012). Edukacja jako priorytet polityki społecznej i najważniejszy czynnik rozwoju społecznego. W: Kotlorz D., Rączaszek A. (red.), Polityka edukacyjna wobec rynku pracy, Katowice: Zeszyty Naukowe Wydziałowe Uniwersytetu Ekonomicznego w Katowicach, 53-62.

Angelika Andrzejczyk, mgr, Uniwersytet w Białymstoku, Wydział Ekonomii i Zarządzania. Od początku kształcenia na poziomie uczelni wyższej związana z Uniwersytetem w Białymstoku. W 2014 r. uzyskała stopień magistra ekonomii i rozpoczęła studia doktoranckie. Głównym zainteresowaniem jest przedsiębiorczość. Laureatka „Diamentowego Grantu”, w ramach którego realizuje projekt pt. „Wpływ edukacji na rozwój postaw przedsiębiorczych".

Angelika Andrzejczyk, MSc, University of Bialystok, Economics and Management Faculty. Since the beginning of education at the university she is associated with the University of Bialystok. In 2014, obtained a master's degree in Economics and began PhD studies. The main interest is entrepreneurship. She is the winner of the Diamond Grant within which realizes the project "The impact of education on the development of entrepreneurial attitudes".

\section{Adres/Address:}

Uniwersytet w Białymstoku

Wydział Ekonomii i Zarządzania

Katedra Nauk o Przedsiębiorstwie

ul. Warszawska 63

15-062 Białystok, Polska

e-mail: angelika.andrzejczyk@gmail.com

Praca naukowa finansowana ze środków budżetowych na naukę w latach 2014-2016 jako projekt badawczy w ramach programu „Diamentowy Grant”. 